Volume 1, Nomor 1, Juni 2021

ISSN 2807-6729

http://jurnal.umsu.ac.id/index.php/JAPK

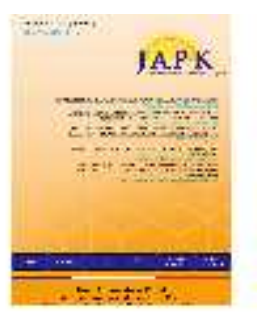

\title{
ANALISIS RANCANGAN PERATURAN TENTANG PERIZINAN TERTENTU DALAM IZIN MENDIRIKAN BANGUNAN DI KABUPATEN DELI SERDANG
}

\author{
Raden Kusnadi \\ Jurusan Ilmu Administrasi Publik, Fakultas Ilmu Sosial dan Ilmu Politik, \\ Universitas Muhammadiyah Sumatera Utara, Indonesia \\ Email: radenkusnadi@gmail.com
}

\begin{abstract}
This study examines the assessment of certain permits in regional permits regarding development in Deli Serdang Regency. The data analysis technique used is a qualitative data analysis technique, namely the data obtained through data collection and then interpreted according to the formulated research objectives. The building permit must be owned by the registration to construct a building within the administrative area, namely Lubuk Pakam City. Meanwhile, building is a building that manages buildings according to city spatial planning and manages building permits that meet administrative requirements and requirements in accordance with the function of the building.
\end{abstract}

Keywords: Services, permits, buildings, building permits

\section{Abstrak}

Penelitian ini mengkaji peraturan daerah tentang pelayanan perizinan tertentu dalam izin mendirikan bangunan di kabupaten Deli Serdang. Teknik analisis data yang digunakan adalah teknik analisis data kualitatif, yaitu data yang di peroleh melalui pengumpulan data kemudian di interpretasikan sesuai dengan tujuan penelitian yang telah di rumuskan. Izin mendirikan bangunan seharusnya wajib dimiliki oleh pemohon untuk mendirikan bangunan didalam wilayah administratif yaitu Kota lubuk pakam. Namun tujuan dari Izin Mendirikan Bangunan adalah untuk penataan bangunan yang sesuai dengan rencana tata ruang kota serta untuk menjaga keandalan bangunan yang memenuhi persyaratan administratif dan persyaratan teknis sesuai dengan fungsi bangunan.

Kata kunci: Pelayanan, perizinan, bangunan, izin bangun 
Analisis Rancangan Peraturan Tentang Perizinan...

Kusnadi R (2021)

\section{PENDAHULUAN}

Implementasi kebijakan merupakan wujud dari tahapan dari suatu kebijakan publik yang sudah dirumuskan. Implementasi Kebijakan Peraturan Daerah Kabupaten Deli Serdang Nomor 6 Tahun 2011 Tentang Perizinan tertentu di kabupaten Deli Serdang merupakan terobosan untuk meningkatkan penataan pola penggunaan ruang kota dalam rangka menertibkan bangunan gedung yang ada. Sejalan dengan laju pertumbuhan Pembangunan Nasional pada umumnya dan perkembangan pembangunan kabupaten Deli Serdang yang menunjukkan adanya kemajuan yang sangat pesat baik di bidang teknologi maupun di bidang pembangunan yang akan dilakukan pemerintah maupun masyarakat, sangatlah berpengaruh kepada tatanan dan wajah kota mendatang, sehingga perlu ada peningkatan kegiatan Pemerintah Daerah untuk mengatur dan menata bangunan.

Kabupaten deli serdang merupakan salah satu daerah otonomi yang berbentuk kabupaten yang berada pada Provinsi Sumatera Utara yang tentunya dalam proses pembangunannya membutuhkan dana yang cukup besar untuk membiayai pembangunan daerah diberbagai sektor. Oleh karenanya kebutuhan akan pembiayaan pembangunan melalui pendapatan asli daerah dianggap cukup menentukan. Sejalan dengan kebutuhan akan pembiayaan yang cukup besar maka pemerintah Kota Medan dituntut untuk berusaha secara aktif untuk menggali dan menciptakan sumber-sumber penerimaan daerah yang potensial seperti pajak dan retribusi daerah.

Izin mendirikan bangunan seharusnya wajib dimiliki oleh pemohon untuk mendirikan bangunan didalam wilayah administratif yaitu Kota lubuk pakam. Namun tujuan dari Izin Mendirikan Bangunan adalah untuk penataan bangunan yang sesuai dengan rencana tata ruang kota serta untuk menjaga keandalan bangunan yang memenuhi persyaratan administratif dan persyaratan teknis sesuai dengan fungsi bangunan. Yang termasuk didalam mendirikan bangunan ini dimulai dari adanya pekerjaan mengadakan bangunan seluruhnya atau sebagian termasuk menggali,menimbun,meratakan tanah yang berhubungan dengan pekerjaan mengadakan bangunan,memperbaiki/renovasi dan menambah bangunan. Dalam pra-penelitian penulis mendapatkan informasi bahwa bangunan yang ada di wilayah Kota lubuk pakam belum tertata dengan rapi dan masih banyak sekali bangunan-bangunan liar dengan kata lain banyak bangunan yang telah berdiri namun belum memiliki izin.

Pada peraturan daerah nomor 5 tahun 2012 tentang retribusi izin mendirikan bangunan pasal 9 (1) dikatakan bahwa setiap orang prbadi atau Badan yang mendirikan bangunan di daerah harus memperoleh IMB untuk pembinaan penyelenggaraan bangunan dari Walikota. Namun sehubungan dengan susahnya masyarakat untuk mengurus IMB artinya 
pengurusan tersebut sangat memakan waktu yang cukup lama, bisa sampai 6 bulan. Hal ini juga menjadi masalah yang sangat besar bagi setiap orang yang ingin mengurusnya di Kota Lubuk Pakam karena dengan tidak adanya IMB tersebut terdapat oknum-oknum yang tidak bertanggung jawab karena mereka melakukan praktik pungutan liar. Dalam pengurusan IMB tersebut juga sering dilakukan praktik pungutan liar(pungli) atau dengan kata lain mereka yang ingin mengurus IMB menggunakan jasa calo.

Tujuan penulisan ini adalah untuk merumuskan permasalahan yang dihadapi dan bagaimana cara-cara mengatasi permasalahan tersebut, baik permasalahan hukum yang dihadapi sebagai alasan pembentukan Rancangan Peraturan Daerah atau sebagai dasar hukum penyelesaian atau solusi permasalahan, Peraturan Daerah Kabupaten Deli Serdang.

\section{KAJIAN PUSTAKA}

Ilmu Administrasi Negara salah satunya berisikan Administrasi Pemerintahan, sangat erat berkaitan dengan berbagai macam kelompok dan perorangan dalam menyajikan pelayanan kepada masyarakat

Selain itu perizinan juga termasuk perwujudan dari Administrasi Publik, yang menunjukkan bahwa pemerintah lebih responsif / lebih tanggap terhadap apa yang dibutuhkan masyarakat / lebih mengetahui cara terbaik untuk memberikan pelayanan publik terhadap masyarakat.25 pada dasarnya dapat diklasifikasikan menjadi dua yaitu:

1. Lisensi (license) yaitu izin yang diperlukan untuk suatu kegiatan tertentu yang tidak memerlukan ruang misalnya SIUP, Izin Prinsip, Izin Trayek, SIM dan lain-lain.

2. Izin (Permit) yaitu izin yang berkaitan dengan lokasi serta pemanfaatan dan kuaitas ruang, misalnya izin lokasi, izin pemanfaatan ruang, misalnya SITU, lingkungan, misalnya AMDAL, HO, konstruksi misalnya IMB, khusus pemanfaatan SDA misalnya SIPA

Ketentuan tentang perizinan mempunyai fungsi yaitu sebagai fungsi penertib dan sebagai fungsi pengatur. Sebaguai fungsi penertib, dimaksudkan agar izin atau setiap izin atau tempattempat usaha, bangunan dan bentuk kegiatan masyarakat lainnya tidak bertentangan satu sama lain, sehingga ketertiban dalam setiap segi kehidupan masyarakat dapat terwujud.

Dalam hal Izin Mendirikan Bangunan, fungsi dari izin bangunan ini dapat dilihat dalam beberapa hal.

a. Segi teknis perkotaan. 
Pemberian izin mendirikan bangunan sangat penting artinya bagi pemerintah daerah guna mengatur, menetapkan, dan merencanakan pembangunan perumahan di wilayah sesuai dengan potensial dan prioritas kota yag dituangkan dalam Master Plan Kota.

\section{b. Segi Kepastian Hukum}

Izin mendirikan bangunan penting artinya sebagai pengawasan dan pengendalian bagi pemerintah dalam hal pembangunan perumahan. Mendirikan bangunan dapat menjadi acuan atau titik tolak dalam pengaturan perumahan selanjutnya.

\section{METODE}

Dalam penelitian ini, teknik analisis data yang digunakan adalah teknik analisis data kualitatif, yaitu data yang di peroleh melalui pengumpulan data kemudian di interpretasikan sesuai dengan tujuan penelitian yang telah di rumuskan. Data yang di peroleh dari hasil wawancara akan di uraikan secara deskriptif dengan analisis kualitatif.

Mengumpulkan data merupakan hal yang sangat penting dalam suatu penelitian.Untuk memperoleh data serta keterangan dari narasumber, maka peneliti menggunakan taknik pengumpulan data sebagai berikut. (1) Teknik pengumpulan data primer, yaitu pengumpulan data yang di lakukan secara langsung pada lokasi penelitian dengan instrumen metode wawancara. Wawancara merupakan teknik pengumpulan data yang di lakukan dengan Tanya jawab secara langsung dengan pihak-pihak terkait atau mengajukan pertanyaan kepada orang yang berhubungan dengan objek penelitian. (2) Teknik pengumpulan data sekunder, yaitu teknik yang di lakukan melalui study kepustakaan yang terdiri dari. (a) Dokumentasi yaitu teknik pengumpulan menggunakan catatan atau dokumen yang ada di lokasi penelitian serta sumber-sumber yang relevan dengan objek penelitian. (b) Study kepustakaan yaitu teknik pengumpulan data dengan menggunakan dengan berbagai literature seperti : dokumendokumen, buku, karya ilmiah, dan laporan penelitian.

\section{PEMBAHASAN}

Kabupaten Deli Serdang merupakan suatu wilayah Provinsi Sumatera Utara dengan peresmian tanggal 1 Juli 1946. Kabupaten Deli Serdang dikenal sebagai salah satu daerah dari 33 Kabupaten/Kota di Provinsi Sumatera Utara.Kabupaten yang memiliki keanekaragaman sumber daya alamnya yang besar sehingga merupakan daerah yang memiliki peluang investasi cukup menjanjikan.Selain memiliki sumber daya alam yang besar, Deli Serdang juga memiliki keanekaragaman budaya, yang disemarakan oleh hampir semua suku-suku yang ada 
di Nusantara. Adapun suku asli penghuni Deli Serdang adalah Suku Melayu yang penamaan Kabupaten ini juga di ambil dari dua kesultanan Melayu Deli

Adapun jenis perijinan yang dilaksanakan oleh dinas penanaman modal dan pelayanan perizinan terpadu satu pintu berdasarkan PERBUB no. 2029 tentang pelimpahan kewenangan poelayanan perizinan terpadu satu pintu pada ayat (2), yaitu:

1. Izin mendirikan bangunan

2. Izin gangguan $(\mathrm{HO})$

3. Izin usaha perdagangan dan tanda daftar perusahaan

4. Izin reklame

5. Izin apotik

6. Izin usaha toko modern (IUTM) beserta izin prinsif lokasi

7. Izin usaha jasa konstruksi

8. Izin usaha jasa konstruksi

9. Izin Peruntukan Penggunaan Tanah

10. Izin Usaha Industri dan Tanda Daftar ndustri

11. Izin usaha dan tanda daftar usaha pariwisata

12. Tanda daftar gudang

13. Izin Laboratorium Kesehatan

14. Izin Usaha Angkutan

15. Izin Trayek

16. Izin Usaha Peternakan dan Tanda daftar peternakan

17. Izin usaha perkebunan untukbudidaya (IUP-B)

18. Izin Usaha Perkebunan Untuk Pengelolaan (IUP-P)

19. Izin usaha perkebunan (IUP)

20. Izin perubahan luas lahan

21. Izin perubahan jenis tanaman

22. Izin perubahan kapasitas pengelolaan hasilperkebunan

23. Izin diversifikasi usaha

24. Izin usaha produksi benih dan tanda daftar produsen, penyalur dan pedagang benih bina.

25. Rekomendasi kesesuaian dengan perencanaan pembangunan perkebunan kabupaten untuk IUP-P yang diterbitkan oleh gubernur.

26. Rekomendasi kesesuaian dengan perencanaan pembangunan perkebunan kabupaten untuk IUP -B yang diterbitkan oleh gubernur. 


\section{Analisis Rancangan Peraturan Tentang Peizinan...}

Kusnadi R (2021)

27. Izin usahaperikanan

28. Izin lingkungan

29. Izin pengumpulan Limbah B3 skala kabupaten

30. Izin pembuangan air limbah ke badan air

31. Izin pemanfaatan bagian jalan.

Pendanaan penyelenggaraan program dan kegiatan penyelenggaraan perizinan tertentu di bidang izin mendirikan bangunan di kabupaten berdasarkan Perda No.6 tahun 2011 tentang retribusi daerah dan Perda no.1 tahun 2015 tentang penetapan retribusi daerah dibebankan langsung pada pemohon dengan ketentuan sesuai ukuran objek yang di izinkan.

Menurut Sugiarto (2013:77) Peraturan Daerah adalah peraturan hukum atau keputusan hukum yang dibentuk oleh Dewan Perwakilan Rakyat Daerah (DPRD) Kabupaten Deli Serdang dengan persetujuan bersama Bupati Kabupaten Deli Serdang. Peraturan daerah tidak boleh bertentangan dengan peraturan perundang-undangan yang lebih tinggi. Proses penyusunan peraturan daerah dimulai dari penyusunan Naskah Akademik untuk mengetahui arah Peraturan Daerah yang diterbitkan. Naskah akademik adalah naskah hasil penelitian atau pengkajian hukum dan hasil penelitian lainnya terhadap suatu masalah tertentu yang dapat dipertanggung jawabkan secara ilmiah mengenai pengaturan masalah tersebut dalam suatu Rancangan Peraturan Daerah Kabupaten Deli Serdang tentang perizinan tertentu sebagai solusi terhadap permasalahan dan kebutuhan aturan dalam penyelenggaraan administrasi pelayanan perizinan untuk masyarakat Kabupaten Deli Serdang.

Secara etimologis, pelayanan ialah "usaha melayani kebutuhan orang lain". Pelayanan pada dasarnya adalah kegiatan yang ditawarkan kepada konsumen atau pelanggan yang dilayani, yang bersifat tidak berwujud dan tidak dapat dimiliki.Pelayanan adalah suatu kegiatan atau urutan kegiatan yang terjadi dalam interaksi langsung antara seseorang dengan orang lain atau mesin secara fisik dan menyediakan kepuasan pelanggan. Menurut Kotler pelayanan adalah setiap kegiatan atas unjuk kerja yang ditawarkan oleh salah satu pihak kepada pihak lain yang secaraprinsip intangileble dan tidak menyebabkan pemindahan kepemilikan apapun, produksinya bisa juga tidak terikat pada suatu produk fisik.Pelayanan publik dapat diartikan sebagai pemberian layanan(melayani) keperluan orang atau masyarakat yang mempunyaikepentingan pada organisasi itu sesuai dengan aturan pokok dantata cara yang telah ditetapkan.

Sebagaimana telah dikemukakan terdahulu bahwa pemerintahan pada hakekatnya adalah pelayanan kepada masyarakat. Ia tidaklah diadakan untuk melayani dirinya sendiri,tetapi untuk melayani masyarakat serta menciptakan kondisi yang memungkinkan setiap anggota masyarakat mengembangkan kemampuan dan kreativitasnya demi mencapai 
tujuan bersama (Rasyid, 1998). Karenanya birokrasi publik berkewajiban dan bertanggung jawab untuk memberikan layanan baik dan profesional.

Di Kabupaten Deli Serdang, masalah pelayanan perizinan pembuatan izin mendirikan bangunan (IMB) dikarenakan kurangnya kesadaran masyarakat untuk mengenai pentingnya pembuatan perizinan. Salah satu indikator keberhasilan pembuatan izin mendirikan bangunan (IMB) adalah tingkat partisipasi masyarakat.Dalam hal ini Kabupaten Deli Serdang dari tahun ke tahun ingin meningkatkan persentase partisipasi masyarakat dalam pembuatan izin mendirikan bangunan (IMB). Maka untuk mencapai kondisi tersebut, pemerintah berusaha menciptakan suatu sistem pelayanan yang optimal, salah satu tindakan pemerintah dalam penciptaan pelayanan yang optimal tersebut adalah dengan dikeluarkannya suatu kebijakan mengenai pembuatan izin mendirikan bangunan, (IMB) melalui Peraturan Daerah Deli Serdang Nomor 06 Tahun 2011 tentang pelayanan perizinan diDinas Penanaman Modal Dan Pelayanan Perizinan Terpaadu Satu Pintu Kbupaten Deli Serdang.

Bagi pemerintah, perizinan tertentu sepertiizin mendirikan bangunan (IMB) yang dilaksanakan secara benar, hasilnya merupakan meminimalisir dari praktek kolusi, korupsi dan nepotisme, mendorong pertumbuhan ekonomi melalui peningkatan investasi dengan memberikan perhatian yang lebih besar pada izin mendirikan bangunan (IMB) yang akurat sekaligus mengakomodasi kepentingan yang pada akhirnya akan mempermudah berbagai urusan yang diperlukan masyarakat berupa pelayanan publik dan perencanaan pembangunan yang efektif, terarah dan terpadu.

Sedangkan sesuai Peraturan Daerah Deli Serdang Nomor 06Tahun 2011 tentang Perizinan Tertentu di Dinas Penanaman Modal Dan Pelayanan Perizinan Terpaadu Satu Pintu Kbupaten Deli Serdang dalam pembuatan izin mendirikan bangunan (IMB).

Izin Mendirikan Bangunan atau biasa dikenal dengan IMB adalah perizinan yang diberikan oleh Kepala Daerah kepada pemilik bangunan untuk membangun baru, mengubah, memperluas, mengurangi, dan/atau merawat bangunan sesuai dengan persyaratan administratif dan persyaratan teknis yang berlaku. IMB merupakan salah satu produk hukum untuk mewujudkan tatanan tertentu sehingga tercipta ketertiban, keamanan, keselamatan, kenyamanan, sekaligus kepastian hukum. Kewajiban setiap orang atau badan yang akan mendirikan bangunan untuk memiliki Izin Mendirikan Bangunan diatur pada Pasal 5 ayat 1 Perda 7 Tahun 2009. IMB akan melegalkan suatu bangunan yang direncanakan sesuai dengan Tata Ruang yang telah ditentukan. Selain itu, adanya IMB menunjukkan bahwa rencana kostruksi bangunan tersebut juga dapat dipertanggungjawabkan dengan maksud untuk kepentingan bersama. 


\section{Analisis Rancan gan Peraturan Tentang Perizinan...}

Kusnadi R (2021)

Setiap orang pribadi atau badan sebelum melaksanakan pembangunan bangunan atau menambah bangunan, prasarana bangunan, renovasi bangunan, dan/ atau bangunan lainnyayang tidak dapat dihitung luasnya, perubahan/revisi Izin Mendirikan Bangunan dan/atauperubahan fungsi Izin Mendirikan Bangunan, Balik nama surat Izin Mendirikan Bangunan,pemecahan Izin Mendirikan Bangunan dan pembuatan duplikat/Photo copy Izin MendirikanBangunan sebagai pengganti Izin Mendirikan Bangunan yang hilang atau rusak, danpenyediaan plank Izin Mendirikan Bangunan harus memiliki IMB dari Bupati dengan lebihdahulu mengajukan permohonan.

Setiap bangunan yang telah terbangun karena keadaan tertentu belum memiliki IMBdiharuskan memiliki IMB dari Bupati.Permohonan Izin Mendirikan Bangunan merupakan permohonan dari setiap orang pribadiatau badan dilengkapi syarat-syarat permohonan kepada Bupati untuk mendapatkan izin.

Izin Mendirikan Bangunan merupakan izin yang diberikan oleh Bupati kepada orang pribadiatau badan untuk mendirikan suatu bangunan atau menambah bangunan dengan tujuan agar desain, pelaksanaanpembangunan, dan bangunan yang dimaksud sesuai dengan Rencana Tata Ruang Wilayahyang berlaku, sesuai dengan Koefisien Dasar Bangunan (KDB), Koefisien Luas Bangunan(KLB), Koefisien Ketinggian Bangunan (KKB) yang di tetapkan, dan sesuai dengan syarat syarat keselamatan bagi yang menempati bangunan tersebut.

\section{KESIMPULAN}

Penyusunan Peraturan Daerah tentang perizinan tertentu di Dinas Penanaman Modal dan Pelayanan Perizinan Terpadu satu Pintu Kabupaten Deli Serdang Sumatera Utara ini merupakan sebuah kebutuhan dan pilihan strategis dalam upaya mengatur secara formal pengembangan akses dan mutu pelayanan dalam hal izin mendirikan bangunan (IMB) di Dinas Penanaman Modal dan Pelayanan Perizinan Terpadu satu Pintu Kabupaten Deli Serdang. Hal ini tidak terlepas dari kondisi semakin berkembangnya permasalahan mengenai pelayanan perizinan yang dibutuhkan masyarakat, maka perlu adanya langkah penyesuaian mengacu kepada regulasi nasional.

Oleh karena itu, diperlukan berbagai intervensi kebijakan yang secara legal disyahkan melalui peraturan daerah. Diharapkan melalui peraturan daerah ini mampu mewujudkan serangkaian peluang kebijakan hukum, diantaranya:

1) Meningkatnya kesadaran masyarakat akan kewajibannya untuk memiliki dokumen perizinan dan berperan serta dalam pelaksanaan izin mendirikan bangunan (IMB).

2) Meningkatnya Sumber Daya Aparatur (SDA) yang berkualitas dan profesional dalam memberikan pelayanan yang terbaik kepada masyarakat. 
3) Meningkatkan kerjasama dengan seluruh elemen masyarakat agar pemahaman masyarakat tentang pentingnya izin mendirikan bangunan (IMB) semakin

4) Meningkatkan pengelolaan informasi pendaftaran perizinan tertentu untuk pendayagunaan data dan informasi dengan tujuan meningkatnya kualitas data yang akurat dan terkini sebagai acuan bagi perumusan kebijakan dan pembangunan pada umumnya.

5) Meningkatkan sarana dan prasarana kerja untuk dapat pencapaian pelayanan yang berkualitas, efektif dan efesien.

6) Meningkatkan sistem pelayanan izin mendirikan bangunan (IMB) dengan berbasis Terintegrasi Secara Elektronik atau Online Single Submission (OSS)

\section{DAFTAR PUSTAKA}

Dunn, William N. 2003. Pengantar Analisis Kebijakan Publik. Yogyakarta : Gajahmada University Press

Em. Lukman Hakim. 2011. Pengantar Administrasi Pembangunan. Yogyakarta: Ar-Ruzz Media

Hanifah, Harsono. 2002. Implementasi Kebijakn dan Politik. Jakarta: Rineka cipta

Inu Kencana Syafiie dan Welasari. 2017. Ilmu Administrasi. Yogyakarta: Pustaka Pelajar Islamy, Irfan. 2009. Prinsip-prinsip Perumusan Kebijaksanaan Negara. Jakarta: Bumi Aksara Muchan. 1982. Pengantar Hukum Administrasi Negara. Yogyakarta: Liberty

Pudyatmoko Sry, 2009.Perizinan Problem dan Upaya Pembenahan. Jakarta: Grasindo.

Siagian, P. Sondang. 2000. Administrasi Pembangunan (Konsep, Dimensi danStrateginya). Jakarta : Bumi Aksara.

Sutedi, Adrian. 2010. Hukum Perizinan Dalam Sektor Pelayanan Publik. Jakarta: Sinar Grafika

Tahir, Arifin. 2014. Kebijakan Publik dan Transparasi Penyelenggaraan Pemerintah Daerah. Bandung : Alfabeta.

Tangkilisan. 2003. Implementasi Kebijakan Publik.Yogyakarta: Yayasan Pembaharuan Administrasi Publik Indonesia 